\title{
The Beginnings of the Cooperation of Free Royal Towns in the Kingdom of Hungary in the Sixteenth and Seventeenth Centuries
}

\author{
István H. Németh \\ National Archives of Hungary, H-1014 Budapest, Bécsi kapu tér 2-4; nemeth.istvan@mnl.gov.hu
}

Received 16 July 2021 | Accepted 7 October 2021 | Published online 3 December 2021

\begin{abstract}
The study presents the possibilities and framework for cooperation between towns in Hungary through the operation of the Town League of Upper Hungary. The cooperation of towns in the Kingdom of Hungary happened primarily through regional relations. At first, the basis for cooperation was provided by common economic interests, but this area broadened considerably in the sixteenth and seventeenth centuries. After the battle of Mohács (1526), the towns of Hungary became full members of the Hungarian Estates. The Kingdom of Hungary, which was part of the Habsburg Monarchy, gained considerable autonomy in internal politics. This was based on a compromise with the Habsburg rulers to ensure protection against the Ottoman Empire. The free royal towns were the least influential members of this country that had strong Estates. Nevertheless, cooperation between the towns became nationwide. The diets provided the forum for all free royal towns in the country to represent their common interests in a coordinated way. There are traces of this nationwide cooperation as early as the mid-sixteenth century, but it was from the early seventeenth century that it was the strongest. The reason was that in those decades state taxes were becoming heavier and more burdensome for towns. This nationwide cooperation was not only manifested in the field of taxation, but from the first quarter of the seventeenth century onwards, it increasingly extended to religious matters. In the background, there was the increasing recatholization of the Habsburg Monarchy. In this special matter, close links were forged also with the otherwise strongly anti-urban lower nobility.

Cooperation between towns worked well, despite the fact that the dominance of Košice (Kassa, Kaschau) clearly influenced the issues that the League members jointly raised. Indeed, the presence of the army, military burdens and denominational issues were most prominent in Košice, the center of the region. The guild association, which determined the internal trade and industrial policy of cities, contributed most to the dominance of Košice craftsmen and merchants in the regional economy. There were significant economic conflicts between Košice and other towns, such as Levoča (Lőcse), Bardejov (Bártfa), Prešov (Eperjes), Sabinov (Kisszeben, Zeben), and Kežmarok (Késmárk). However, the union of towns was also beneficial for the smaller towns, as on their own they would have been unable to represent their interests so effectively.
\end{abstract}

Keywords: Habsburg Monarchy, estates, urban policy, urban advocacy, confessionalism, taxation, internal trade 
The historiography of Hungarian towns has mostly presented the elements of urban policy based on the laws passed by parliaments. However, this approach is rather onesided because it reports mainly the demands strongly defined by the counties, in other words, by the nobility's regional organisations. Laws passed, however, were very often not implemented, therefore were not necessarily a veritable reflection of the economic, social, and political realities of towns. According to the image we have been presented with, towns in Hungary were politically rather weak, with the enforcement of their interests hardly tangible. It is a fact that because of the excessive political weight of counties controlled by the nobility, nobles living in towns were not under the authority of the local burghers' municipality, nor were several areas of regulating the economy. These facts led earlier scholarship to the conclusion that in parallel with the strengthening of the state in the seventeenth century, towns in Hungary were growing weaker, and their development was stalled by these processes. ${ }^{1}$ Recent research, however, has challenged this interpretation. Using the Town League of Upper Hungary as a case study, the present paper introduces the fundamental elements of Hungarian urban policy and the main features of cooperation between towns. Through the examples of towns located in other parts of the country, I will place the towns' association into a wider perspective, arguing that issues of urban policy are not characteristic of Upper Hungary only, but may be representative of the country's entire network of towns. In addition to outlining the areas of cooperation, my main goal is to demonstrate the political framework and the role of the estates within which towns enforced their interests, as well as the methods they applied.

As far as the cities of the early modern period are concerned, their social structure and class system were considerably more open than in the Middle Ages. The municipalities were gradually more integrated into the centralizing state administration. This was caused by changes in public administration, on the one hand, and by the ever more interwoven relationships of burghers and the nobility, on the other. The latter phenomenon led to the Estates of the realm blending with one another, being the most important feature of the early modern period. Additionally, it was one of the basic phenomena of early modern times that the state increased its power: the state administration's scope of authority expanded. Initially, the state infiltrated cities primarily in fields related to the development of the armed forces and public administration. Starting from the sixteenth century, military centers of the cities, fortified towns, official seats and residences were the first to see these factors change in the legal, social and public administration fields. ${ }^{2}$

In the next period, i.e., from the seventeenth century onwards, the state apparatus tried to get an insight into the everyday life of a growing section of society

1 Szűcs, "Das Städtewesen in Ungarn."

2 Asch and Duchhardt, Der Absolutismus - ein Mythos?; Asch, "Kriegsfinanzierung, Staatsbildung." 
and subsequently, also to intervene into it. This effort went hand in hand with the centralized - and later the absolutist—state introducing centralized rules in matters previously managed exclusively by the estates of the realm and their representatives. These were mostly concerned with the relations of peasants and landlords directed by the state in the eighteenth century, or matters of religion, pastoral care, healthcare, dealing with poverty, etc. Matters of war and military financing-which were state competences at the time-developed under the control of the absolute monarch; in accordance with the novel way of exercising power, centralization occurred also in other fields of the state (i.e., tax administration, jurisdiction, tasks related to certain units of public administration, etc.) and became tasks of the state administration, backed by the monarch's legitimation. ${ }^{3}$ In economic history, this transformation is described as the birth of the fiscal state, which is an exact reflection of the purely economic and financial relationship between causes and solutions. These phenomena also impacted the cities that were under the control of the monarch. The income from the activities of the bourgeoisie (the ever-increasing taxes, trade income, etc.) formed an increasing part of state proceeds, therefore the state and wealthy commoners shared more and more common interests. ${ }^{4}$ Some call this the 'advent of state bureaucracy' in towns and cities, the integration of cities into the state administration, or, with some exaggeration: the 'nationalization' of municipalities. As a consequence of the changes in state administration and in municipal politics, by the eighteenth century the previously isolated municipal life had come to an end and was replaced by municipalities integrated into modern states, developing at an unprecedented pace. ${ }^{5}$

The pace of urban development in Hungary is not comparable to that in Western Europe. The cities were formed rather late, their economic strength was much weaker than that of the prominent European cities, and the economic influence of their citizenry was more limited. It was only in the first decade of the fifteenth century that the settlements, later called 'free royal towns', with estate privileges, were established thanks to the urban policy of the Angevins and Sigismund of Luxembourg (1387-1437). In the Late Middle Ages, these towns were not certain

3 Duchhardt, "Absolutismus - Abschied von einem Epochenbegriff?"; Henshall, The Myth of Absolutism: Change and Continuity; Heinrich, "Staatsaufsicht und Stadtfreiheit"; Vierhaus, Deutschland im Zeitalter des Absolutismus.

4 Bonney, ed., The Rise of the Fiscal State in Europe; Hart, The Making of a Bourgeois State; Brien and Hunt, "The Rise of a Fiscal State"; Cavaciocchi, ed., La fiscalità nell'economia Europea.

5 About the 'nationalization' of cities, see Gerteis, Die deutschen Städte in der frühen Neuzeit, 73-80. See also: Rügge, Im Dienst von Stadt und Staat; Tilly and Blockmans, eds, Cities and the Rise of States; Cowan, Urban Europe; Riis and Strømstad, eds, Le pouvoir central et les villes; Marraud, De la ville à l'état; Chittolini, "Städte und Regionalstaaten"; Brady, Turning Swiss; Schlögl and Sawilla, eds, Urban Elections and Decision-Making. 
to have the right to participate in the diets as members of the estates. Towards the end of Sigismund of Luxembourg's reign, there were attempts to include the cities in the assemblies of the estates, but only from the mid-fifteenth century were they regularly and frequently invited to participate in the assemblies, and this practice ceased at the beginning of the sixteenth century. ${ }^{6}$ This coincided with the increase of the nobility's political influence to the extent that they no longer needed the resolution of the Estates. By the sixteenth century, however, the sovereignty of the free royal towns was complete. Following the battle of Mohács (1526), they were always invited to attend the part-assemblies and the diets. ${ }^{7}$

Following the struggle for the throne between János Szapolyai and (Habsburg) Ferdinand I, it became clear in the eyes of the leading politicians in the Kingdom of Hungary defeated by the Ottoman Empire that the country's defence could be guaranteed only by a state united under the Austrian archduke. Integrated into the complex state of the Habsburg Monarchy, the internal political life of the Kingdom of Hungary was determined by the Hungarian estates. Thus, in the province of the Monarchy with the strongest nobility, the counties and free royal towns were able to manage their affairs almost independently, with little state influence. ${ }^{8}$ The completion of the estate privileges of free royal towns granted them a permanent forum to represent their interests at the national level. After the battle of Mohács, the towns' estate rights could be considered stable, as they were invited to all diets, except for the one in 1542. Being invited to the diet was the only sure sign of a settlement being acknowledged as a free royal town, because this issue was unregulated up until 1608. The 1608 diet stated that the status of a free royal town was explicitly linked to the acceptance of its envoys by the other estates' envoys. This was an indication of the recognition of the given town as a real member of the estate society, its envoys' rights being considered the same as those of other estates attending the diets. The towns' uncertain status among the other estates is also clear from the importance they attached to their parliamentary presence. In the early period of the estate system, we learn mainly of the ways the towns tried to evade their obligation to send out envoys. In contrast, in the sixteenth and seventeenth centuries, this kind of abstention by the towns happened only in the years immediately following the battle of Mohács. But from the middle of the sixteenth century onwards, no town council would have its envoy stay away from the diet, as they considered their parliamentary presence important, and would have seen it as a violation of their rights as an estate if they had not been invited. ${ }^{9}$

$6 \quad$ Kubinyi, König und Volk.

7 Friedrichs, Urban Politics in Early Modern Europe; Pils and Niederkorn, eds, Ein zweigeteilter Ort?

8 Pálffy, The Kingdom of Hungary, 177-91.

9 H. Németh, "Representatives in a Changing World," 4-5. 
In the diet, the towns were among the smallest and least influential estates, and this was reflected not only in their ranking (they formed the fourth estate). The urban envoys were quite passive in most affairs, indicating their political weakness among the estates. The nobility regarded urban delegates as inferior. This is illustrated by several atrocities in which the county delegates publicly shamed the town envoys in the diets. ${ }^{10}$ According to the seventeenth century order of affairs, only after the counties were the towns allowed to register their grievances. The towns were thus relegated to the background in the assemblies' general debates, and were not expected to speak unless they had to defend their own affairs. In negotiations, they could receive support from other estates only in religious matters. From the first quarter of the seventeenth century onwards, counties and towns in the Kingdom of Hungary with the Protestant (Lutheran and Calvinist) denominational majorities sought to cooperate on religious issues. The recatolization, which was a source of heated debate primarily during the reigns of Ferdinand III (1637-1657) and Leopold I (1657-1705), brought together towns and the county nobility with otherwise conflicting political and economic interests. In religious matters, it sometimes happened that county envoys, who were otherwise traditionally anti-urban, sided with the denominational grievances of the towns. Moreover, in these cases, certain prominent personalities among qualified urban delegates could become an important political factor. On special occasions representing the estates, town envoys were also able to play their rightful, but not truly prominent role. ${ }^{11}$ Representatives of the fourth estate were delegated to the committee receiving the monarch on his arrival in the country in the same number as the counties, and at coronation ceremonies the towns' representatives played a similar, but smaller role. ${ }^{12}$ The same was true of the delegations sent by the lower chamber to the prelates and the monarch: in addition to the county delegates, they always included one or two town envoys. In other areas of urban lobbying and advocacy, however, the towns were quite effective at conducting their affairs. During the diets, or through their envoys specially delegated to the central bodies in Vienna or to the Hungarian offices in Bratislava (Pozsony, Pressburg, Prešporok), their lobbying capacity was much stronger than in the open negotiations of the diets. The towns' interests were also supported by the dignitaries in contact with them, or by the clients' network that had already been established on a permanent basis. The latter were the secretaries or clerks of the Hungarian Court Chancellery and the Court Chamber, to whom the towns regularly paid money or various gifts. ${ }^{13}$

10 SAP MMB Acta diaetalia Nr. 690. fol. 255. 28-29. 05. 1655.

11 H. Németh, "Agenten, Ratgeber, Lobbyisten," 231-32.

12 Lackner, Lackner Kristófnak, 134-37; Pálffy, "Krönungsmähler in Ungarn, Teil 1"; Pálffy, "Krönungsmähler in Ungarn, Teil 2."

13 H. Németh, "Agenten, Ratgeber, Lobbyisten," 230-31. 


\section{The Town League of Upper Hungary}

Thus, it was during the reign of Sigismund that free royal towns emerged in the Upper-Hungarian (now Eastern Slovakian) region: namely, the settlements of Košice (Kassa, Kaschau), Levoča (Lőcse, Leutschau), Bardejov (Bártfa, Bartfeld), Prešov (Eperjes, Eperies), and finally Sabinov (Kisszeben, Zeben) became free royal towns. The same legal status, with roughly the same estate privileges, laid the foundations for the formation of the Town League of Upper Hungary (Oberungarische Städtebund) in the same period. The nature of the alliance is reflected by the fact that at their first known meeting they took joint decisions on economic matters, which in the first decades of the alliance was based purely on the protection of economic interests. In this period, political advocacy was not a feature of the League yet, mainly because the towns had not yet formed an independent estate, and no national forum had been created to defend their common political interests. From the early sixteenth century onwards, this trend changed and the League's activities were extended, partly because of the strengthening of the towns' municipal status, and partly because of the new domestic political situation created by the Ottoman conquest with a profound impact on both the economy and society.

After its formation in the fifteenth century, the League represented the interests of the free royal towns of the region. The alliance was expanded in the mid-seventeenth century (1655), with the free royal town of Kežmarok (Késmárk, Käsmark). Internal tensions are illustrated by the fact that Kežmarok applied for admission to the League within the year that the diet recognized it as a free royal town, but due to economic differences with Levoča, Kežmarok had to wait a few more years to become a permanent member of the alliance. The first time we see Kežmarok, it is together with the other towns in the discussion of the jointly equipped army, a state duty of the towns. Then, from 1658 onwards the alliance was increasingly more involved in other matters, mainly in fending off the growing pressure imposed by the county nobility. At this time, the Kežmarok envoys already attended meetings to discuss national urban policy problems. What is more, in 1659 the associated towns called a meeting because of an economic conflict between Kežmarok craftsmen and the 13 towns of Szepes (Spiš, Zips) County. By the early 1660s, Kežmarok had become a full member of the League. It was a permanent participant in the alliance's meetings, taking an interest in all matters the other towns were involved in.

The wars of reconquest against Ottoman rule (1686-1699) also affected the urban network, notably the number of free royal towns. In the liberated territories, one after another, the former free royal towns regained their letters of privilege from the Royal Hungarian Court Chancellery. Debrecen was granted the status of a free royal town in $1693^{14}$ and Baia Mare (Nagybánya, Frauenbach) at the end of the 
seventeenth century. As soon as Debrecen obtained the privileges of the monarch, it inquired through its envoys about the rights and practices that came with the status of a free royal town. At this time, the League changed its policy and intensified its efforts to maintain good relations with the new free royal towns at the turn of the seventeenth and eighteenth centuries, mainly because the new practice was that the towns should pay their taxes, provide soldiers and pay for the services required by the army, in part jointly. Despite their common affairs, however, it was only in these matters that the League of Towns negotiated with the new towns. In other areas of the League's interests, there was no joint action. The composition of the League therefore did not change, only the towns' political strategy differed from previous strategies. The governmental urban policy of the period (strong control, chamberlain's measures against the towns, etc.) demanded stronger links between free royal towns, but the League's framework was no longer suitable for effective political representation. After the 1711 Treaty of Szatmár, cooperation between free royal towns started to be even tighter in defence of their common interests, but the new state-led urban policy meant that the League's activities were negligible in the eighteenth century. ${ }^{15}$

The cooperation of the towns in the League was ensured by regular meetings or meetings called for specific agendas (an order from the ruler or the Chamber of Spiš). These meetings were mainly initiated by Košice, Prešov and Levoča, and reflect the balance of power within the association. The absolute superiority of Košice is shown by the fact that, when other towns proposed a town meeting, the opinion of the Košice Council was always sought: the place, time and necessity of the meeting were almost always decided by Košice Council. The usual practice was for the Prešov residents to summarise the news received and then send it on to the Košice Council. The Košice Council decided on the place and time of meetings, and if the assembly decided that they had to act jointly on a matter, the Košice delegate was certainly among them. The frequency of meetings varied greatly, with the cities holding an average of two or three meetings in politically quiet years. If there was an urgent matter to discuss, city delegates would meet more than once. Prior to the meetings, the towns would regularly communicate, and the documents related to the matter and each other's proposals would be exchanged by letter. It was also frequent that the members of the League would send joint embassies to a higher government body, and their instructions were coordinated in advance. ${ }^{16}$

The functioning of the alliance shows that among the towns of Upper Hungary, Košice clearly played a dominant role. Košice was counterbalanced mainly by Prešov, which had been rising in the sixteenth century, and by Levoča, an old economic rival. Even though the members of the League always emphasised in their statutes that

15 H. Németh, Várospolitika és gazdaságpolitika, vol. 1, 72-161.

16 H. Németh, “Agenten, Ratgeber, Lobbyisten," 222-23. 
they would act together, there were several occasions when meetings were held to the exclusion of some towns. There may have been several reasons for this related to internal tensions within the alliance. On the one hand, due to the overwhelming economic superiority of Košice, other cities joined forces without Košice in order to formulate their own policies. ${ }^{17}$ In some cases, the free royal towns of Sáros County (Bardejov, Prešov, and Sabinov) also engaged in separate politics, mainly to protect their domestic trade interests; in most cases, however, the importance of the issues involved led the alliance to intervene later, and problems that could be considered local became common affairs of the League. In this spirit, each town's complaints about its own affairs were also discussed in joint meetings, mainly in order not to harm each other's interests. Nevertheless, the towns' interests were often at odds with those of other towns in the federation, especially when they were linked to the region's economic and commercial relations. Thus, these matters were sometimes concealed from the others. For example, in 1608 the envoys from Levoča travelled to the Diet in separate carriages, which suggested that during the journey they were probably discussing their own interests to the exclusion of the others. ${ }^{18}$

Despite internal conflicts, the League proved to be effective in external advocacy. Through the jointly operated information network, even a small town like Sabinov could be informed of all the important developments in the region. The League of Towns maintained close links with the permanent local organs of the central authorities that had been established from the mid-sixteenth century onwards: the Chamber of Spiš, set up in 1567, and that of the Upper Hungarian Captain Generalcy, organised in the same period. The Chamber acted as an advisory and executive body for the most important economic policies affecting the free royal towns. Its importance for the interests of the towns is therefore indisputable. It was in the best interests of the towns to maintain good relations with the captain generals in charge of the military forces stationed in the region, since the military burden was the heaviest obligation for burghers, whose support was outstanding in protecting the region on the border between the Principality of Transylvania and the Kingdom of Hungary. These institutions were much faster and more effective sources of information than others. As the headquarters of the Chamber and of

17 According to the second point of the Covenant of Cities of 1588: "Zum Andern. Wöllen Wir benanten Fünff Frey Städt das alte VerPündnüß mit einander eintrechtig, streiff unndt Vest halten undt zue fürfallenden nöthen einander auff allerley Weis undt weg, redlich undt treglich beystehen, unndt zue hülff Khomen, so viell Imer müglich.” The third point is: “... vonn Einer oder mehrern auß benannten Fünff Städten das Ihr oder Ihnen beschwerlich sein möcht, etwas begeren, oder aufferlegen würde, alß dann khaine Freystadt [oder] ohne der andern Vorwissen unndt Willen nichts bewilligen oder dargeben solle." SAP MML XIII/83. Kassa, 17. 07. 1588.

18 H. Németh, “Agenten, Ratgeber, Lobbyisten," 223; H. Németh, Várospolitika és gazdaságpolitika, vol. 1; AMK H I. 5263/38. Löcse, 20. 03. 1608. 
the Captain Generalcy, Košice's role in this respect is outstanding. It was not by chance that members of the League of Towns so often turned to the Košice Council to obtain information on various matters related to the Chamber or the captain general. In more than one case, important information came directly from the chief captain, who informed the towns mainly about the military situation, but was also available to their envoys whenever they needed help. ${ }^{19}$

The administrative reforms introduced by Leopold I weakened this relatively smoothly functioning network. From the 1670s onwards, the management of local bodies was increasingly under the indirect control of the Viennese government, and the completely different situation created by the wars of reconquest provided a unique political opportunity for the appointed imperial generals to assume even greater powers than previous governors-general. These changes caused enormous disruption to the politics and information networks of the Town League of Upper Hungary. Its members were unable or unwilling to move in new directions (the system that had been set up did not offer much opportunity to do so). The information networks that had been built over the previous century and a half were no longer available to towns. In contrast to the methods of the sixteenth and seventeenth centuries, the central government in Vienna completely excluded the lower bodies from (economic) political decision-making. Unlike before, local bodies did not function as bureaucracies familiar with the issues at stake and, therefore, having an advisory role in the problems and requests they were confronted with, but were only and exclusively bodies implementing the measures of the Viennese Court. Wellestablished channels of communication had thus disappeared, and the disintegrating League of Towns could no longer find new channels of information that were as effective as before. ${ }^{20}$

Before the changes of the 1670s described above, the federal framework granted by the League was also much cheaper in terms of advocacy costs than if a town had tried to play politics on its own. Advocacy consumed a considerable amount of money. In the seventeenth century, an envoy would cost between 600 and 700 florins, in addition to the amount that towns paid in advance for the needs of their delegates, meaning that the total cost could be more than a thousand florins. In addition to payment in cash, the expenditure was further increased by the many barrels of wine delivered to Vienna as a gift. For instance, at the end of the sixteenth century, the envoys of the League gave 20-25 barrels of wine to the military commander-in-chief of Upper Hungary. Although the costs were indeed high, it was more advantageous for the towns to send joint embassies, even if a longer embassy

19 H. Németh, “Agenten, Ratgeber, Lobbyisten," 228.

20 H. Németh, “Agenten, Ratgeber, Lobbyisten," 231-32; H. Németh, Várospolitika és gazdaságpolitika, vol. 1, 193-207. 
was very rare, while the meetings of the towns were all the more frequent. At the end of the seventeenth century, the cost of an embassy to Prešov or Levoča was less than 100 florins, while an embassy to Vienna would rarely cost less than 1,000 florinsand this figure did not include gifts for officials. It is clear from all this that individual towns had a vested interest in participating in the League, even if its policy was sometimes heavily influenced by the interests of the Council of Košice. ${ }^{21}$

\section{Urban cooperation in the diets}

The most important forum for urban lobbying was undoubtedly the diet, where urban envoys could express their views either within the framework of the League or in cooperation with other free royal towns. The towns could only rely on themselves, i.e., on the fourth estate, or on negotiations outside the diet. Here, too, the framework granted by the League was of great importance, since at the alliance's meetings preceding the diets the members formulated their positions jointly and prepared their joint petitions, which were submitted either in the imperial audiences or in the form of the estate's grievances. Even the discussion of common grievances was usually preceded by lengthy correspondence, so that on the day of the meeting they endeavoured to put the main grievances in writing. The consultation was not limited to joint requests and complaints, but each town presented its instructions given to its parliamentary envoys in order to coordinate their tasks. The same kind of cooperation can be observed in the mining towns of Lower Hungary (now Western Slovakia), where this was also a compulsory point in the envoys' instructions. ${ }^{22}$ From the beginning of the seventeenth century onwards, joint politicking was more widespread, and the towns were urged to cooperate with the envoys of all the free royal towns.

Cooperation between the towns grew even closer during parliamentary negotiations. With regard to grievances and bills against the towns, or issues relating to military tribute and recatolization, this parliamentary cooperation was characteristic not only of the seventeenth century, but dates back to the sixteenth. Traditionally, the towns' delegates met in the mayor's house or in the town hall of Bratislava, which due to the Ottoman wars, from the 1520s was the seat of diets. It would even occur in the sixteenth century that the envoys of Upper Hungarian towns entrusted the envoys of Bratislava with representing their interests in the diet. In the course of parliamentary negotiations, it was common for urban envoys to meet in each other's

21 H. Németh, "Agenten, Ratgeber, Lobbyisten," 230-31.

22 The only difference between mining towns and other towns was the mining activity conducted in their area under state supervision. However, the state supervised only the mines and their output, not the towns. Their political role was the same as that of free royal towns. 
residence to coordinate their strategy concerning grievances and petitions against towns in general, or against individual towns, but impacting all the towns. In the 1655 diet, for example, they met altogether eight times to discuss the issues raised and draft petitions and grievances together. ${ }^{23}$

After an overview of the towns' means of common defence of interests, the next section discusses the main issues of early modern Hungarian urban politics, i.e., the areas in which the towns acted together to defend their interests. Of the numerous topics, the issue of military and state taxes imposed on the towns stands out, closely linked to the political situation that had a decisive influence on the Kingdom of Hungary in the sixteenth and seventeenth centuries.

\section{The first signs of urban policy: military burdens and state taxation}

The early modern history of the Kingdom of Hungary was shaped by the conquest of the Ottoman Empire, the Ottoman challenge and the new political formation that emerged in the first half of the sixteenth century. The southern and central parts of the country, together with the medieval capital of Hungary, Buda, came under Ottoman rule. The Transylvanian Principality, which had broken away from the Kingdom, was a separate state as a vassal of the Ottoman Empire until 1690. The territory of the Kingdom of Hungary was limited to the western and northern parts of the former country, along which a defence system against the Ottomans had to be established. The Kingdom of Hungary could only ensure its defence as part of the Habsburg Empire. Its state revenues were insufficient to build up and maintain the defence system and to feed the 16,000 to 17,000 soldiers. The state revenues other provinces of the Habsburg Monarchy provided for the common defence were vital. It was also necessary to exploit the country's own resources. ${ }^{24}$ The history of the Kingdom of Hungary in the sixteenth and seventeenth centuries, and thus urban policy, was fundamentally determined by the war-economy and the relationship between the army and society. Consequently, fortress towns (Festungstadt) similar to those in Western Europe were developed. Győr, Komárom and Nové Zámky (Érsekújvár, Neuhäusl), typical representatives of this type, always remained market towns under seigneurial control. ${ }^{25}$ In addition, some free royal towns were transformed into captains' headquarters (Košice, Varaždin [Varasd, Warasdin]), where the settling military was no longer under the jurisdiction of the municipal government, but under the captains.

23 H. Németh, "Agenten, Ratgeber, Lobbyisten," 224-27.

24 Kenyeres, "Die Kosten der Türkenabwehr."

25 Gecsényi, “Ungarische Städte im Vorfeld der Türkenabwehr Österreichs”; Pálffy, “The Border Defense System." 
In these cities, the powerful captains-general intervened in several areas of the town's life, thereby fundamentally violating urban rights. Judicial power over the military was vested in the chief captain or his war council. The municipal council's jurisdiction over the so-called 'mixed' cases between the military and the burghers was also impaired since the municipal council had to share jurisdiction with the captain and his magistrate when their fellow citizens were in conflict with the military. In worse cases, the royal captains sometimes violated this right, although it was guaranteed and prescribed by the monarch. The town's revenue was also greatly reduced by the taverns and slaughterhouses set up for the military because along with the soldiers came craftsmen who, under the powerful protection of the captain-general, were able to ply their trade independently of the guilds of the towns. The soldiers were housed in the burghers' houses, and the difference in mentality and lifestyle between citizens and soldiers led to numerous clashes. The military in the cities did, however, provide some economic advantages for the bourgeoisie. Merchants were active in supplying the army, meeting the higher demands of the garrison and the military. The civilian officials of the general headquarters also provided a significant market for urban vendors. The powers of the captains-general, however, overturned the medieval urban autonomy. The penetration within their walls of a powerful force that the ruler endowed with wide-ranging rights, that was alien to the citizens. ${ }^{26}$

Due to the constant state of war in the sixteenth and seventeenth centuries, the towns' taxes and military burdens increased steadily. ${ }^{27}$ By the second half of the seventeenth century, from an initial 30-40,000 florins, town taxes went up to $170-180,000$ florins. Although this represented a small proportion (2-4 percent) of the country's total disposable income, according to the reports of the Hungarian Chamber, up to the mid-seventeenth century, these sums could be counted on more than, for example, the taxes paid by the counties. This is evidenced by the fact that by the end of the sixteenth century, towns had not accumulated significant arrears. This factor was particularly important during the years of the Fifteen Years' War, when military expenditure was several times higher than before, and parliaments met annually to vote with the estates on the taxes needed for the campaigns against the Ottomans. Obviously, this factor greatly increased the ability of the cities to assert their interests, since the ruler could always rely on their taxes (even if they were not enormous sums), and arrears did not accumulate. As early as the sixteenth century, the free royal towns had already cooperated in diets, and the need for cooperation, especially in matters of state and war taxes, became more pronounced in the seventeenth century. The reasons for this date back to the so-called Long Turkish

\footnotetext{
26 H. Németh, "Befestigte Städte und Festungsstädte."

27 For the period of the Thirty Years' War, see: Kaiser, Waffen, Geld, Soldaten; Limberger and Ucendo, Taxation and Debt in the Early Modern City.
} 
or Fifteen Years' War, when the growing burden of warfare forced towns to forge closer links at the assemblies held almost annually. At the diet of 1599, the towns' envoys were united in their opposition to hand over the management of their taxes to the estates, but they were also united in their opposition to the demand that towns should provide transport capacity. However, it was the post-war tax hike that eventually aligned the policies of all the towns. In this period, the free royal towns' taxes were increased, and on several occasions, were levied without parliamentary authorisation. That is why, in early 1613, the town of Bratislava proposed a meeting at which all the royal towns would be represented, so that they could formulate a common position before the diet and take concerted action in all forums against the increase and perpetuation of their taxes. Their proposal is unique in the history of urban politics in Hungary. From the 1630s and 1640s onwards, it was customary to collect the same taxes voted in parliament for two or three years. This heightened pressure, together with the economic downturn caused by the Thirty Years' War, led to the inability of towns to pay their taxes regularly, and by the last third of the century, they had accumulated substantial arrears. The amount was so large that the monarch was forced to waive some of it. The towns were under enormous pressure, as on several occasions the ruler threatened to take their demesnes from the town councils in exchange for unpaid taxes. Accordingly, the practice of towns taking joint action continued, but only minor results, such as the remittance of some of the tax arrears, were achieved. ${ }^{28}$

\section{Burghers and monarchic interests: the importance of military transport in urban politics}

Since everything during this period was subordinated to the defence against the Ottomans and the Transylvanian princes, it strengthened the towns' influence that they reinforced the garrison of the surrounding fortresses with permanent soldiers they paid for. The number of troops thus available varied. Up to the the last quarter of the sixteenth century, the towns of Upper Hungary paid for nearly 300-500 soldiers, and from the 1560s to the second half of the seventeenth century, for 200. The costs were considerable, as they almost equalled the amount of the municipal tax and represented a constant burden. ${ }^{29}$ In Western European countries, the urban bourgeoisie's influence was greatly enhanced by the substantial loans that urban citizens supported the ruler with. The bourgeoisie of the Kingdom of Hungary did not have such significant capital power, but as early as the sixteenth century, trends

28 H. Németh, "Die finanziellen Auswirkungen."

29 H. Németh, "Die finanziellen Auswirkungen," 776. 
similar to those in the West can be observed, albeit to a smaller extent. ${ }^{30}$ Towns and their citizens played a significant role in the supply of arms and food to the still nascent defence system. In these years, due to the disorganised nature of the army supply, the central chambers relied heavily on the towns for subsistence and loans, which they generally provided on a regular basis. In addition to financial loans, the transport of munitions, clothing and food to the field armies was also a significant service, as it was provided by the towns that had a more developed industrial background. The value of the goods supplied by the towns and the size of their serial loans, however, did not reach the level of the Chamber's supply from the country's large landowning families. This fact had a significant impact on the Viennese Court's urban policy in Hungary, which after the 'long war' tended to turn towards the western theatres of war, and increased the role of the large landowning nobility, which took a larger share of the defence burden than the towns. In addition to the towns' obligatory military supplies, the role of merchants, who were the economic elite of towns, should be emphasised. Their monthly loans, which were made because of the difficulties of the money transfer system, ensured the stable supply of fortresses. Because of the presence of a large military, merchants had a steady market for the wine that they were unable to sell at a high profit abroad. ${ }^{31}$

Even though the Hungarian bourgeoisie's economic potential was far weaker than that of their Western European counterparts, the constant and substantial military supplies and large loans offered by the towns and their citizens were certainly a positive factor. ${ }^{32}$ The towns and their special functions guaranteed a secure background for the military leadership: their supplies were always delivered punctually, quickly, and to the best of their possibilities. Taking advantage of the manufacturing base available to them through their guild-based crafts, towns played a vital role in the transport of industrial products, military goods, clothing, and processed foodstuffs, such as bread. In this respect, they even enjoyed a monopoly over the surrounding landlords. The involvement of towns and their citizens in army transportation points to the presence of potential economic resources. This is an indication that the sixteenth century Hungarian towns must have been better off than previously thought. Since the loans granted by the towns and the fees of their transport services were repaid late by the chamber, they exerted a negative rather than a positive effect. Nevertheless, they certainly contributed to the towns' and their citizens' increasing influence. In almost each case, in the sixteenth century the

30 Zunckel, Rüstungsgeschäfte im Dreissigjährigen Krieg.

31 H. Németh, Várospolitika és gazdaságpolitika, vol. 1, 370-438.

32 Tallett, War and Society; Marraud, De la ville à l'état, la bourgeoisie parisienne, 108-71; Meyzie, Crédit public, crédit privé et institutions intermédiaires; Sánchez, Military Entrepreneurs and the Spanish Contractor State; Felix and Dubet, The War Within. 
towns were able to have their requests accepted by the ruler, thus gaining various economic advantages. The citizens taking part in the army provision were granted nobility, and occasionally even courtly status. In the sixteenth century, they still played an important additional role in the local supply of the army. However, the towns' political influence was limited by the bourgeoisie's capital poverty. Their role could have been strengthened by being in charge of army transports and disbursing loans, but compared to large landowners, their importance was insignificant. From the turn of the sixteenth and seventeenth centuries onwards, the large landowning nobility was more active than before in maintaining the defence system, and by raising their own military, they compensated for the shortfall of the royal military. Since the Court was much more dependent on the nobility, their political interests determined the political relations of the diets even more. This phenomenon is evidenced by the anti-urban bills the assemblies passed in the mid-seventeenth century. ${ }^{33}$

\section{Among the Estate categories: towns and county nobility}

The interests of the cities also prevailed in the extension of their jurisdiction to the nobility moving to the cities and the citizens who were granted nobility. The counties were increasingly trying to remove the urban nobility and noble citizens from the authority of the city council. ${ }^{34}$ The roots of the problem go back to the sixteenth century. At the same time as the military, another problematic element arrived in the free royal towns. The noble settlers driven by the Ottomans northwards from the south, some of whom arrived with the military, jeopardized the powers of urban authorities, just like the soldiers. Although sixteenth century laws regulated their situation in favour of the towns, the statutes of the mid-seventeenth century removed the nobles almost entirely from the jurisdiction of the town and placed them under the jurisdiction of the counties. This applied as much to urban nobles as to noble burghers who had led a bourgeois life but had been granted a charter of arms. Most of the nobles who fled to the towns, however, paid annual taxes for their town houses in accordance with the urban regulations, complied with the provisions laid down by the towns for importing wine, and accepted the authority of the town council. Such trends were even more noticeable among the noble burghers. In their case, the counties also sought judgement by the administrative leader of the county (supremus comes) rather than by the town council. They were expected to share in the taxes levied on the counties, and to contribute to the payment of soldiers to be raised. In terms of their way of life, the urban nobility, however, were not part of the

33 H. Németh, "Die finanziellen Auswirkungen," 776-77.

34 Endres, "Adel und Patriziat in Oberdeutschland"; Andermann and Johanek, eds, Zwischen Nicht-Adel und Adel; Driel, Pohl, and Walter, eds, Adel verbindet - Adel verbindt. 
county nobility but rather of the urban bourgeoisie. When granted nobility, typically, they did not even give up their former occupations. Until the mid-seventeenth century, there is no indication of a general tendency for them to come under the county rather than the town jurisdiction. ${ }^{35}$

From the middle of the seventeenth century onwards, we find only isolated cases where the county provided a way out for a noble burgher condemned by the town. By the 1660s, the political situation had changed to the extent that the towns were usually forced to settle with the noble burgher who was suing, with the counties united behind them, in some cases even taking the case to the diet. The strong antitown sentiment in the mid-seventeenth century and the gradual eclipse of the free royal towns made it necessary for the towns to cooperate ever more closely. Their joint (more vehement than before) politicking, or rather the towns' self-defence, was understandable, since the nobility's attacks were not in fact directed against individual towns but against the whole of the Fourth Estate. A good example of this is the meeting held in 1644 in the town of Trnava, (Nagyszombat, Tyrnau), where, after the successful campaign of the Transylvanian Prince György II Rákóczi, the prince, the Hungarian Estates and the commissioners of King Ferdinand III gathered to draw up another compromise. Here, the representatives of the royal towns acted in unison and tried to convince the ruler of their own rights against the county nobility interfering in urban affairs, and in this case, they were mostly successful. We can cite another example of the growing cooperation between towns. At the diets of $1646 / 47$ and 1649, the noble estates' complaints against the burghers of Košice and the majority of the resulting laws infringed the privileges of all other towns as well by allowing nobles to import wine into the towns tax free, or recognising the jurisdiction of the counties over the town nobility. As a common reaction, the free royal towns' delegates marched together before the Chapter of Bratislava to stage a solemn protest against the insults they had suffered. ${ }^{36}$

Due to the unity of the towns and the local political power relations, most noble burghers refused to be under the jurisdiction of the counties, and paid their taxes to the town treasury, rather than to the county. Even at the beginning of the eighteenth century, the idea of county taxation was rejected on the grounds that they were sworn to the town and not to the county, and were primarily town citizens. Thus, thanks to the towns' united political action and in accordance with everyday practice, the county could not bring these citizens and their urban proprieties entirely under its jurisdiction. Nevertheless, the rights of urban self-government were curtailed in several areas. This is clearly visible in the multi-storey houses built

35 Pils and Niederkorn, eds, Ein zweigeteilter Ort?; Federmayer, "Šlachta uhorskej metropoly."

36 Bessenyei, "A szabad királyi városok"; H. Németh, Várospolitikai és gazdaságpolitika, vol. 1, 500-14; H. Németh, "Städtepolitik und Wirtschaftspolitik," 346-49. 
by the nobility and the aristocracy in the towns and in the fact that, from the turn of the seventeenth and eighteenth centuries, the county's offices were moved into the towns. In the case of noble burghers, the county repeatedly obliged them to pay taxes just like the low nobility, and in the event of a noble uprising, to serve in the armed forces.

In addition to taxes and military burdens, the closest cooperation between towns was on matters concerning the privileges of the free royal towns, especially the admission of new ones. In the early seventeenth century, they were still successfully resisting interference from the monarchs and counties. The individual towns enjoyed the support of the entire Fourth Estate in the face of interference from the monarch and the duchies. This was also the case when the monarch tried to force the city of Bratislava to include Catholics among its leaders. The growing recatholization further mobilised the towns. Thus, in the negotiations on the house taken from the Calvinists by the Catholics in Trnava at the 1609/1610 Diet, there was as much common defence of their interests as there was ten years later over the issue of the authority over the great church in Bratislava. At the diet of 1637/38, a common platform of Protestant estates (both Lutherans and Calvinists) was established, and the urban envoys participated very strongly in this community until the diet of 1687 , even though this cooperation was strictly forbidden above the estates. Throughout the century, the towns assisted each other in religious matters, and were supported by the counties in this matter. The Protestant Estates in the towns and counties supported the towns against the Jesuit Order in the towns, just as they supported them in the matter of the seizure of town churches. The cause brought the towns to a common platform, with the majority of the counties against state confessionalism, and on this issue they were able to gain considerable political support from their former opponents. On several occasions, skilled urban delegates emerged as spokesmen for the Protestant estates in domestic political debates. ${ }^{37}$

\section{Individual interests over collective economic interests}

For towns, the most important issues-beyond the defence of their own privileges and jurisdiction-were related to the economic interests of their burghers. As we have seen, the creation of the Town League of Upper Hungary was also necessitated by a common economic interest, i.e., the regulation of loans. However, the economic policies of the cities in both the sixteenth and seventeenth centuries were exposed to the ravages of incessant war. It is not primarily the unstable trade routes that are to be considered here, since (strange as it may seem) this was not the case for the

37 H. Németh, "Representatives in a Changing World," 5-9. 
entire period. The problem was much more the ban on exporting certain products, such as wine, copper, nitrate, or horses, which were important export items and necessary for military purposes, especially for the supply of border forts. Such regulations were mainly imposed during campaigns or when poor harvests meant that less food was available to the army. ${ }^{38}$ In this situation, with all matters being subject to warfare, towns were only able to ensure that their merchants could continue their activities unhindered, especially in the sixteenth century. In the seventeenth century, the Viennese court's wars in Western Europe significantly increased the role of Hungarian revenues, and the amount of taxes levied also increased. The largest and most reliable of the Chamber's revenues was the customs duty collected on foreign trade (the so-called "harmincad" or "tricesima"). In order to raise it, by the first half of the seventeenth century, almost all towns had lost their exemption from customs duties, which they had retained for most of the sixteenth century. In addition, in order to maintain the defence system neglected by the wars in Western Europe, from 1635 an additional customs duty was introduced, added to the traditional tax, from which almost no one was granted an exemption. ${ }^{39}$ Moreover, regulations were introduced in the wine trade, raising further the revenue from customs duties, but minimizing the role of Hungarian merchants. Under the Chamber's measures, domestic merchants were forbidden to export wine, while Polish merchants were allowed to trade freely (on payment of customs duties). This made the towns' trading privileges almost pointless, as Polish merchants were able to trade with Chamber licences. Because of the overwhelming financial problems, momentarily the treasury considered the towns' loss of revenue less important than to increase the volume of its secure customs revenue, and the towns were unable to do much in this area. ${ }^{40}$

This monetary policy coincided with the large landowners' increasing involvement in foreign trade. Landowners with large estates had a much more favourable market position than urban merchants. Their business activity was boosted by the fact that the nobility increasingly demanded that their serfs pay their taxes in the form of produce. The fact that the period was one of monetary decline obviously played a role in this, but the acquisition of marketable foodstuffs was also very attractive to the nobility. ${ }^{41}$ The towns' political activity in relation to foreign trade, though far from being free from internal contradictions, can be considered uniform. The towns acted in concert to maintain their foreign trade privileges, their exemption from customs duties, and their market position, and as a result were still

38 Kaiser, Waffen, Geld, Soldaten.

39 Kenyeres, "Die Kosten der Türkenabwehr."

40 H. Németh, "Städtepolitik und Wirtschaftspolitik," 349-51; H. Németh, Várospolitika és gazdaságpolitika, vol. 2, 28-43, 71-91, 95-113.

41 Winner, "Adeliger Stand und bürgerliche Hantierung." 
achieving considerable success in the sixteenth century. The towns' defence of their interests in monetary policy, which became critical during the monetary crisis of the seventeenth century, may also be regarded as united. They were able to obtain fairly advantageous decisions in the diets and from local state officials, while town merchants' role in foreign trade continued to be significant. The only exceptions were the measures taken in the seventeenth century to increase customs duties on foreign trade, an area in which the towns were only partially successful. ${ }^{42}$

The towns' cooperation extended further than these areas. They also strongly represented their interests in the regulation of internal trade and the production and sale of agricultural and industrial products, which were of great importance to burghers. The towns of Upper Hungary created separate regulations to protect their guilds, and also acted within the framework of the League to protect their domestic trade. It was here that the interests of Košice, the leader of the alliance, were clearest represented. On the one hand, the defence of internal trade was carried out against the nobility, who refused to accept the privileges of urban merchants in their own customs posts. It was only at the end of the seventeenth century that the towns became disadvantaged in this respect. In the fifteenth and sixteenth centuries, the towns in Upper Hungary gradually set up a common guild alliance to promote their economic interests and protect their guilds. The essence of this alliance was that the guilds of the same industry of each town were grouped into a common "mother guild". The members of the alliance adopted each other's guild rules and the alliance was the higher authority in matters between the member guilds. The League's economic policy was dominated by the interests of the burghers of Košice, thus the guild policy was also controlled by this town. This was also reflected in the fact that by the turn of the sixteenth and seventeenth centuries, the guilds of the members of the League, as well as those of Szepes County-which were formerly affiliated to the town of Levoča-joined the main guilds of Košice out of economic necessity.

However, as a result of an agreement between the members of the League, the practice developed that guilds in the region's market towns did not have to join the main guild of Košice, but the League's guild alliance. ${ }^{43}$ Therefore, the superiority of the guilds in Košice was not evident, and the League's other members also benefited from the advantages of the mother guild. Nevertheless, in this field as well, Košice's domination was clear. From the first quarter of the seventeenth century onwards, there are growing numbers of signs that with the help of the guild alliance, the League was trying to tighten its control over the market towns in its market area. The free royal towns of the League forced the seigneurial market towns in Upper

42 H. Németh, "Städtepolitik und Wirtschaftspolitik," 349-51.

43 Market towns were settlements owned by landlords which had their own smaller municipality. They could enforce their interests mostly against their landlords or with their assistance. 
Hungary to join their guild alliance. This was the case despite the considerable help that market towns received from their landlords. There were many ways of putting pressure on them. For example, they allowed market town masters to enter their own urban markets only if the given market town acknowledged the supremacy of the guild alliance over him. Recognition of the training of apprentices in market towns was subject to the same condition. For the League's towns, this had several advantages: the masters of the urban guild in the market towns had access to favourable market opportunities, and the masters of the market towns were under strong control. ${ }^{44}$ In the famous wine region of Tokaj-Hegyalja, which was of great importance to the League's towns and the basis of their wine trade, they jointly influenced the regulation vineyard workers' wages ${ }^{45}$ The regional policy of the Town League is well reflected in the spread of the common code of urban law. The collection of laws compiled by the members of the League in 1649 was successively taken over by the region's market towns over the next decade and was consistently applied in their own legal systems. ${ }^{46}$

\section{Conclusion}

It can be concluded that urban policy in Hungary in the sixteenth and seventeenth centuries was based on cooperation, first at regional level, subsequently, on an increasingly broader scale. In addition to the better-known Town League of Upper Hungary, the mining towns of Lower Hungary and the free royal towns of Western Hungary formed similar but as yet undiscovered alliances of towns, or, even if in a non-institutionalized framework, they certainly harmonized their interests. In Bratislava, the location of powerful central administration, signs of state control are tangible from the first quarter of the seventeenth century onwards, but its trends are similar to those of other towns. In the sixteenth century, this harmonization of interests happened on a smaller scale, while from the seventeenth century onwards it was gradually intensified. It was at this time that due to the increasing levels of state taxation, the towns joined forces and coordinated their actions. They formed a united front in the diet as the fourth estate, and the town envoys pursued a consultative policy of coordinating interests with the other towns. The intensity of the coordination of interests was strengthened by the state's attempts to impose ever higher taxes on the towns and by interfering more into the towns' denominational

44 H. Németh, "A szabad királyi városok mezővárosi politikája."

45 This was the main wine-growing region of vital importance for Upper Hungarian towns' wine trade. The towns and their citizens possessed considerable vineyards there whose output was marketed mainly in Kraków in Poland.

46 H. Németh, "Städtepolitik und Wirtschaftspolitik," 351-52. 
composition. At the same time, the counties were increasingly seeking to intervene in the affairs of the nobles living in the towns, which also justified the towns' unified political action. Each of these town groups was headed by a major commercial center, such as Košice, Bratislava, Sopron (Ödenburg), Banska Štiavnica (Selmecbánya, Schemnitz) and Banská Bystrica (Besztercebánya, Neusohl). The individual interests of these towns also played a decisive role in determining the policies of the regional urban cooperation. The cooperation may have been weakened by the fact that on several occasions these leading towns carried out their political activities to the detriment of the interests of smaller towns. Nevertheless, the unity of urban alliances, and even more of the towns as a whole, had a positive effect, and the towns represented their interests effectively and successfully in national forums up to the end of the seventeenth century. Indeed, the economic potential of the larger towns had an impact on the overall political representation of interests, so that the influence of larger towns on political decision-making could benefit smaller ones, while the interests of the larger towns were effectively supported by the presence of smaller ones. Cooperation was most effective at the regional level, with cooperating towns maintaining a very tight grip on local internal trade and industrial policy.

\section{Sources}

Archív Mesta Košice (AMK) [Archive of the City of Košice]

Supplementum Halagianum, Listy a listiny (H I.)

Štátny archív v Prešove (SAP) [State Archive in Prešov]

pracovisko Archív Bardejov, Magistrat Mesta Bardejova (MMB) [City of Bardejov]

špecializované pracovisko Spišský archív v Levoči, Magistrat Mesta Levoča (MML) [City of Levoča]

\section{Literature}

Andermann, Kurt, and Peter Johanek, eds. Zwischen Nicht-Adel und Adel. Vorträge und Forschungen / Konstanzer Arbeitskreis für Mittelalterliche Geschichte 53. Stuttgart: Thorbecke, 2001.

Asch, RonaldG. and Heinz Duchhardt. Der Absolutismus - ein Mythos? Struktur-wandel monarchischer Herrschaft in West- und Mitteleuropa (ca. 1550-1700). CologneWeimar-Vienna: Böhlau Verlag, 1996. doi.org/10.7788/boehlau.9783412314682

Asch, Ronald G. "Kriegsfinanzierung, Staatsbildung und ständische Ordnung im Westeuropa im 17. und 18. Jahrhundert.” Historisches Zeitschrift 268 (1999): 635-71. doi.org/10.1524/hzhz.1999.268.jg.635 
Bessenyei, József. “A szabad királyi városok jogainak csorbítása” [Diminishing the Rights of Free Royal Towns]. Történelmi Szemle 33, no. 3-4 (1991): 255-63.

Bonney, Richard, ed. The Rise of the FiscalState in Europe: c. 1200-1815. Oxford: Oxford University Press, 1999. doi.org/10.1093/acprof:oso/9780198204022.001.0001

Brady, Thomas A. Turning Swiss: Cities and Empire, 1450-1550. Cambridge Studies in Early Modern History. Cambridge-New York: Cambridge University Press, 1985. Brien, Patrick K. O', and Philip A. Hunt. "The Rise of a Fiscal State in England, 1485-1815.” Historical Research 66, no. 160 (1993): 129-76. doi.org/10.1111/j. 1468-2281.1993.tb01806.x

Cavaciocchi, Simonetta, ed. La fiscalità nell'economia europea secc XIII-XVIII: atti della "Trentanovesima Settimana di Studi", 22-26 aprile 2007. Florence: Florence University Press, 2008. doi.org/10.36253/9788884537034

Chittolini, Giorgio. "Städte Und Regionalstaaten in Mittel- und Oberitalien Zwischen Spätem Mittelalter und Früher Neuzeit.” In Res Publica. Bürgerschaft in Stadt Und Staat. Tagung Der Vereinigung Für Verfassungsgeschichte in Hofgeismar Am 30./31. März 1987, edited by Gerhard Dilcher, 179-200. Der Staat Beiheft 8. Berlin: Duncker \& Humblot, 1988.

Cowan, Alexander. Urban Europe: 1500-1700. London: Arnold, 1998.

Driel, Marten van, Meinhard Pohl, and Bernd Walter, eds. Adel verbindet - Adel verbindt: Elitenbildung und Standeskultur in Nordwestdeutschland und den Niederlanden vom 15. bis 20. Jahrhundert / Elitevorming en stanscultur in Noordwest-Duitsland en de Nederlanden van de 15e tot de 20e eeuw. PaderbornVienna: Schöningh, 2010.

Duchhardt, Heinz. "Absolutismus - Abschied von einem Epochenbegriff?" Historisches Zeitschrift 258 (1994): 113-22. doi.org/10.1524/hzhz.1994.258.jg.113

Endres, Rudolf. "Adel und Patriziat in Oberdeutschland.” In Ständische Gesellschaft und soziale Mobilität, edited by Winfried Schulze, 221-38. Munich: Oldenbourg, 1988. doi.org/10.1524/9783486595536-013

Federmayer, Frederik. “Šlachta uhorskej metropoly v pomoháčskom období. (Archontologicko-genealogický náčrt problematiky)" [The Nobility of the Hungarian Metropolis in the Pomeranian Period. (Archontological-genealogical outline of the problem)]. Forum historiae 4, no. 2 (2010). Accessed 27 October 2021. www. forumhistoriae.sk/main/texty_2_2010/federmayer.pdf

Felix, Joel, and Anne Dubet, eds. The War Within. Private Interests and the Fiscal State in Early-Modern Europe. Cham: Palgrave Macmillan, 2018. doi.org/ 10.1007/978-3-319-98050-8

Friedrichs, Christopher R. Urban Politics in Early Modern Europe. London-New York: Routledge, 2002. doi.org/10.4324/9780203131343

Gecsényi, Lajos. "Ungarische Städte im Vorfeld der Türkenabwehr Österreichs. Zur Problematik der ungarischen Städteentwicklung." In Archiv und Forschung: das 
Haus-, Hof- und Staatsarchiv in seiner Bedeutung für die Geschichte Österreichs und Europas, edited by Elisabeth Springer and Leopold Kammerhofer, 57-77. Munich-Vienna: Verlag für Geschichte und Politik, 1993.

Gerteis, Klaus. Die deutschen Städte in der frühen Neuzeit. Zur Vorgeschichte der 'bürgerlichen Welt. Darmstadt: Wissenschaftliche Buchgesellschaft, 1986.

H. Németh, István. "A szabad királyi városok mezővárosi politikája a XVII. században"

[Market Town Policy of the Free Royal Towns in the $17^{\text {th }}$ Century]. In A mesterség iskolája. Tanulmányok Bácskai Vera 70. születésnapjára, edited by Zsombor Bódy, Mónika Mátay and Árpád Tóth, 229-43. Budapest: Osiris Kiadó, 2000.

H. Németh, István. "Agenten, Ratgeber. Lobbyisten. Das Kommunikationsnetzwerk der ungarischen Städte und die Städtepolitik (16-17. Jahrhundert)." In Die frühneuzeitliche Stadt als Knotenpunkt der Kommunikation, edited by Martin Holý and Tomáš Sterneck, 217-28. Berlin: LIT Verlag, 2019.

H. Németh, István. "Befestigte Städte und Festungsstädte in Ungarn im 16-17. Jahrhundert." In Město a jeho hradby [The City and Its Walls], edited by Olga Fejtová, Martina Mař́ková, and Jiří Pešek, 458-72. Prague: Archiv Hlavního Města Prahy, 2019.

H. Németh, István. "Die finanziellen Auswirkungen der osmanischen Expansion auf die Städteentwicklung in Ungarn." In La fiscalità nell'economia europea secc XIIIXVIII: atti della "Trentanovesima Settimana di Studi", 22-26 aprile 2007, edited by Simonetta Cavaciocchi, 771-80. Florence: Florence University Press, 2008.

H. Németh, István. "Representatives in a Changing World: Characteristics of Urban Advocacy at the Turn of the Seventeenth and Eighteenth Centuries." Hungarian Historical Review 10, no. 1 (2021): 3-34. doi.org/10.38145/2021.1.3

H. Németh, István. "Städtepolitik und Wirtschaftspolitik in Ungarn in der Frühen Neuzeit." In Geteilt - Vereningt. Beiträge zur Geschichte des Königreichs Ungarn in der Frühneuzeit (16-18. Jahrhundert), edited by Krisztián Csaplár-Degovics, and István Fazekas, 329-55. Berlin: OEZ-Berlin Verlag, 2011.

H. Németh, István. Várospolitika és gazdaságpolitika a 16-17. századi Magyarországon. A felső-magyarországi városszövetség [Urban Politics and Economic Policy in $16^{\text {th }}-17^{\text {th }}$ Century Hungary. The Upper-Hungarian League of Towns]. Vol. 1-2. Budapest: Gondolat - Magyar Országos Levéltár, 2004.

Hart, Marjolein C. 't. The Making of a Bourgeois State: War, Politics and Finance during the Dutch Revolt. Manchester: Manchester University Press, 1993.

Heinrich, Gerd. "Staatsaufsicht und Stadtfreiheit in Brandenburg-Preußen unter dem Absolutismus (1660-1806)." In Die Städte Mitteleuropas im 17. und 18. Jahrhundert, edited by Wilhelm Rausch, 155-72. Beiträge zur Geschichte der Städte Mitteleuropas 5. Linz: Trauner Verlag, 1981.

Henshall, Nicholas. The Myth of Absolutism: Change and Continuity in Early Modern European Monarchy. London: Longman, 1992. 
Kaiser, Michael. "Waffen, Geld, Soldaten. Köln und die Kriegswirtschaft.” In Köln in unheiligen Zeiten. Die Stadt im Dreißigjährigen Krieg. Begleitband zur Ausstellung des Kölnischen Stadtmuseums vom 14. Juni bis 5. Oktober 2014, edited by Stefan Lewejohann, 93-101. Cologne-Weimar-Vienna: Böhlau, 2014. doi.org/10.7788/boehlau.9783412217938.93

Kenyeres, István. "Die Kosten der Türkenabwehr und des Langen Türkenkrieges (1593-1606) im Kontext der ungarischen Finanzen des 16. und 17. Jahrhunderts.” In Das „Blut des Staatskörperers”, edited by Peter Rauscher, Andrea Serles, and Thomas Winkelbauer, 19-41. Munich: De Gruyter, 2012. doi.org/10.1524/9783486718287.19

Kubinyi, András. König und Volk im spätmittelalterlichen Ungarn: Städteentwicklung, Alltagsleben und Regierung im mittelalterlichen Königreich Ungarn. Studien zur Geschichte Ungarns 1. Herne: Schäfer, 1998.

Lackner, Kristóf. Lackner Kristófnak, mindkét jog doktorának rövid önéletrajza [A short curriculum vitae of Kristóf Lackner, Doctor in both laws]. Translated by Gergely Tóth. Sopron város történeti forrásai C/5. Sopron: Györ-Moson-Sopron Megyei Levéltár Soproni Levéltára, 2008.

Limberger, Michael, and José Ignacio Andrés Ucendo, eds. Taxation and Debt in the Early Modern City. New York: Routledge, 2012.

Marraud, Mathieu. De la ville à l'état, la bourgeoisie parisienne, XVII e-XVIII siècle. Paris: Albin Michel, 2009.

Meyzie, Vincent. Crédit public, crédit privé et institutions intermédiaires. Monarchie française, monarchie hispanique, XVI ${ }^{e}-X V I I I^{e}$ siècles. Limoges: PULIM, 2012.

Pálffy Géza. "Krönungsmähler in Ungarn im Spätmittelalter und in der Frühen Neuzeit. Weiterleben des Tafelzeremoniells des selbständigen ungarischen Königshofes und Machtrepräsentation der ungarischen politischen Elite. Teil 1." Mitteilungen des Österreichiscen Staatsarchivs 115, no. 1-2 (2007): 85-111. doi.org/10.7767/miog.2007.115.14.85

Pálffy Géza. "Krönungsmähler in Ungarn im Spätmittelalter und in der Frühen Neuzeit. Weiterleben des Tafelzeremoniells des selbständigen ungarischen Königshofes und Machtrepräsentation der ungarischen politischen Elite. Teil 2." Mitteilungen des Österreichiscen Staatsarchivs 116, no. 1-2 (2008): 60-91. doi.org/10.7767/miog.2008.116.14.60

Pálffy, Géza. "The Border Defense System in Hungary in the Sixteenth and Seventeenth Centuries." In A Millennium of Hungarian Military History, edited by László Veszprémy and Béla Király, 111-35. War and Society in East Central Europe 37. = East European Monographs 621. = Atlantic Studies on Society in Change 114. New York: Columbia University Press, 2002.

Pálffy, Géza. The Kingdom of Hungary and the Habsburg Monarchy in the Sixteenth Century. Hungarian Studies Series 18. New York: Boulder, 2009. 
Papp Klára. “A szabad királyi oklevéltől az országgyülési becikkelyezésig” [From the Free Royal Charter to the Enrolment in Parliament]. In Debrecen város 650 éves [Debrecen, the 650-Year-Old Town], edited by Attila Pál Bárány, Klára Papp, and Tamás Szálkai, 301-19. Speculum Historiae Debreceniense 7. Debrecen: Debreceni Egyetem Történelmi Intézete - Hajdú-Bihar Megyei Önkormányzat, 2011.

Pils, Susanne Claudine and Jan Paul Niederkorn, eds. Ein zweigeteilter Ort? Hof und Stadt in der Frühen Neuzeit. Innsbruck-Vienna: Studien-Verlag, 2005.

Riis, Thomas and Poul Strømstad, eds. Le pouvoir central et les villes en Europe du XVe siècle aux débuts de la révolution industrielle: Actes du colloque de la Commission internationale pour l'histoire des villes au Danemark, Copenhague 1976. Copenhagen: Danish Committee for Urban History, 1978.

Rügge, Nicolas. Im Dienst von Stadt und Staat: der Rat der Stadt Herford und die preußische Zentralverwaltung im 18. Jahrhundert. Göttingen: Vandenhoeck \& Ruprecht, 2000.

Sánchez, Rafael Torres. Military Entrepreneurs and the Spanish Contractor State in the Eighteenth Century. Oxford: Oxford University Press, 2016.

Szűcs, Jenö. "Das Städtewesen in Ungarn im XV-XVII. Jh." In La Renaissance et la Réformation en Pologne et en Hongrie, 1450-1650, edited by György Székely and Erik Fügedi, 97-164. Studia Historica Academiae Scientiarum Hungaricae 53. Budapest: Akadémia Kiadó, 1963.

Schlögl, Rudolf and Jan Marco Sawilla, eds. Urban Elections and Decision-Making in Early Modern Europe, 1500-1800. Cambridge: Cambridge Scholars, 2009.

Tallett, Frank. War and Society in Early Modern Europe 1495-1715. London: Routledge, 1992.

Tilly, Charles, and Wim Blockmans, eds. Cities and the Rise of States in Europe, A.D. 1000 to 1800. Boulder: Westview Press, 1994.

Vierhaus, Rudolf. Deutschland im Zeitalter des Absolutismus: (1648-1763) / Rudolf Vierhaus. Göttingen: Vandenhoeck und Ruprecht, 1978.

Winner, Gerhard. “'Adeliger Stand und bürgerliche Hantierung'. Die sieben landesfürstliche Städte und die ständischen Gegensatze in Oberösterreich während des 16. Jahrhunderts." Historisches Jahrbuch der Stadt Linz 13 (1959): 47-81.

Zunckel, Julia. Rüstungsgeschäfte im Dreissigjährigen Krieg: Unternehmerkräfte, Militärgüter und Marktstrategien im Handel zwischen Genua, Amsterdam und Hamburg. Schriften zur Wirtschafts- und Sozialgeschichte 49. Berlin: Duncker \& Humblot, 1997. 